\title{
Introduction: Introducing Philosophy of the City
}

\author{
Jules Simon ${ }^{1}$ \\ Accepted: 10 February 2021 / Published online: 13 March 2021 \\ (c) The Author(s), under exclusive licence to Springer Nature B.V. part of Springer Nature 2021
}

At the beginning of the twenty first century, cities have become places where the majority of humans now live, and this trend continues unabated. According to the United Nations Department of Economic and Social Affairs, 55\% of all humans now dwell in cities and that is expected to increase to almost $70 \%$ by 2050 . The shift of human populations from rural to urban areas could add another 2.5 billion people to cities across the globe and $90 \%$ of that increase is expected to occur in Asia and Africa. Projections by the U.N. predict that just three countries will account for $35 \%$ of that astronomical growth: India will add 416 million city dwellers; China 255 million; and Nigeria 189 million. These are astounding projections and, if they come true, make it all the more imperative to focus attention on all matters having to do with cities in the coming decades.

How movements and research agendas start, continue, and productively flourish remains an open question but there is something to be said about Max Scheler's philosophy of Kairos, that is, that authentic and effective human action happens-personally and collectively-within the nexus of "the call of the hour." This was the case a decade ago, in 2011, when several individuals 'heard' the call of the hour and formed an international research group, Philosophy of the City Research Group, which is currently being co-directed by Jules Simon (myself, from the University of Texas at El Paso, USA), Sanna Lehtinen (Aalto University, Finland), Shane Epting (Missouri University of Science and Technology, USA), Ron Sundstrom (University of San Francisco, USA), and Michael Nagenborg (University of Twente, Netherlands). ${ }^{1}$ There are increasingly many ways to study cities, their function, relevance for constituting meaning for humans both individually and communally, and their growing importance for contributing to the health or disease of the planet earth and its myriad species of flora and fauna. A case can be made, however, that the "call of the hour" is to

Jules Simon

jsimon@utep.edu

1 University of Texas at El Paso, El Paso, USA once again intentionally take up the task of philosophizing the city - to theorize the city-which is best done with the cooperation of those who have been practically engaging in 'urban studies' in the last several decades and those intellectuals who have been influencing the very formation and normative functions of cities for more than two millennia, namely, philosophers. Thus, led primarily by the efforts of Shane Epting, a graduate student at that time, and supported by a small group of philosophers including Jules Simon and Mike Menser (Brooklyn College), the first Philosophy of the City conference was organized and staged at Brooklyn College in 2013. The Philosophy of the City Research Group (PotC Research Group) was founded with that act with Mike Menser as its first President and in the spirit of Hannah Arendt's philosophy of action, the PotC Research Group embarked on organizing an ambitious series of conferences and workshops with the intention of generating novel philosophical ways of sharing ideas and initiatives of thinking the city. As Arendt noted, all authentic thinking, and thus authentic action, is verified in its originality and efficacy by how its consequences necessarily remain unpredictable and 'infinite.' Over the years that have followed, the horizons of the PotC Research Group have continued to grow and flourish in many, potentially infinite, different ways. This special issue sets out just one of those many ways.

I will say more about the international Philosophy of the City Research Group towards the end of this Introduction.

\section{From Ideal City to the Cities of Our Lived World}

Understandably, clarifying the origins, multi-faceted functions, and meaning of the city has figured prominently in the philosophical tradition, with Plato and Aristotle getting the philosophical ball rolling more than two millennia ago. In the histories of Greek city states and the Roman empire,

\footnotetext{
${ }^{1}$ For the homepage of the Philosophy of the City Research Group, see: https://philosophyofthecity.org/philosophy-of-the-city-researchgroup/.
} 
many of their ideas about the essential role that cities played and should play for individual and collective human development remain central for understanding the ethical, aesthetic, and ontological course of human intersubjectivity and environmental relations in and with the world. Plato's view of what he called the Kallipolis - the beautiful cityincluded a tripartite structure that aligned parts of the human soul with the psychological constitution of the city along with their respective virtues and the different classes that would represent those elements ${ }^{2}$ :

\begin{tabular}{llll}
\hline $\begin{array}{l}\text { Part of the } \\
\text { human soul }\end{array}$ & $\begin{array}{l}\text { Psychological } \\
\text { constitution }\end{array}$ & Virtue & Class of the City \\
\hline Reason & Aristocratic & Wisdom & Guardians \\
Spirit & Timocratic & Honor & Auxiliaries \\
Appetite & $\begin{array}{l}\text { Oligarchic } \\
\text { Democratic } \\
\text { Tyrannical }\end{array}$ & Temperance & Producers \\
& & \\
\hline
\end{tabular}

As is well-known, the Greek, Platonic ideal city supported the aristocratic virtues of a patriarchal household economy and was constructed around phenomena such as tyranny, racial privilege, slavery and, for Aristotle's more practically oriented politeia, the inevitability of property-based, warring, tribal societies. In the more 'ideal' Platonic version, two classes guarded the city and its constitution (ruling and auxiliary guardians) and one produced what the city needed. The Guardians are the ruling class of the Ideal City and used the tools of propaganda, eugenics, falsehood, and censorship in order to rule. The Auxiliaries are a military class, with the main task to conduct the Ideal City's wars and to enforce the Constitution, trained to be aggressive and ruthless with foreigners but gentle with their own citizens. The Producers are the workers who produce and deliver the goods needed for all of the people of the city while the Philosopher-king is a Guardian who was to be carefully educated in military, mathematics, government, and philosophy in order to lead those same people of the city. These 'structures' remained as 'ideal' normative guidelines by which cities could be generally described for their actual, historical manifestations in the world and the extent to which they approximated to those ideals.

Aristotle based his ideas of the city on Plato's ideas but was critical of his teacher's over-idealism and thus came up with what he thought was a more practical model. He based his model on three basic forms of political governance: rule of the many, rule of the few, and rule of the one. These three basic forms were further analyzed according to his philosophy of the golden mean, of moderating between

\footnotetext{
${ }^{2}$ See https://philosophy-models.blog/2019/01/15/plato-about-theideal-city-in-the-republic/.
}

extremes: at its best, the first form enabled what he called politeia (as previously noted) and at its worst, democracy; the second form, at its best, was aristocracy and at its worst, oligarchy; and the third, also at its best, was monarchy and at its worst, tyranny. For Aristotle, monarchy and aristocracy were ideal forms of government and so he thought a third, more practical form, had to be created which synthesized the strengths of both of those ideals, namely, the politeia. This form combined the rule of the few with the rule of law, thus incorporating what he thought were key elements of Plato's theory-guardianship, self-sufficiency, and the rule of law. In the process, he thought that he came up with a reformed ideal city which would be more practical and thus something that could actually be constructed. Again, as I noted above, this included land ownership and rulership by lot as indispensable elements of the ideal polis, while dispensing with what he thought were unrealistic — or perhaps undesirableconcepts such as distributive justice and voluntary rule.

While we have the ideal city on the one hand, which evolved in time to become the city of industry and agriculture and specialization, problems arose through the concentration of wealth, division of labor, specialization and alienation. Many of these problems could be traced to the philosophically supported ideas of the city set in motion by Plato and Aristotle, such as the idealized hierarchies of Plato's class system or the commitment to hereditary land ownership and dismissal of the principle of distributive justice by Aristotle. More obvious was the normative establishment of the separation of males and females and masters and slaves with the former of both pairs retaining dominance and power 'by nature' over the latter members of the two pairs. For Aristotle, the natural hierarchy of men over women served to establish the economy of the household, that is, of economy in general, and the natural hierarchy of masters over slaves served to found the village, which was the aggregate of households. Out of the aggregation of villages, arose the city-state(s). This rough outline of the origin of cities out of the theories of the ideal city, based on the Ancient Greek philosophies of Plato and Aristotle, would serve as an ideal model to ground individual and social human behavior in Western societies for the next 2000 years.

In that long, complex interlude, though, Augustine and Thomas Aquinas philosophically redirected the arc of intentionality of how and why humans gathered together to form cities. Both Christian philosophers drew significantly, and respectively, on the ideas of Plato and Aristotle for their ideas of the city and political thought. However, they dramatically altered the conception of the purpose and thus the possible phenomenological orientations of the citizens of medieval cities by introducing the element of divine right into how the function of cities should be and indeed were conceived. For these two Fathers of the Church and spiritual leaders of imperial empires, cities were no longer merely 
socio-political conglomerates rooted in earth, environment, and secular time but became testing grounds for aligning oneself with the will and laws of God. Authority for how one organized social bodies and modes of living together, including the construction and formation of cities, was no longer based on the logical and normative relationship of individual to group and caste/class but on how one understood the will and purpose of God. For Augustine, a neo-Platonist, this took the form of orienting oneself to an ideal city-the City of God, about which he wrote a lengthy book that provided a goal or a kind of divine blueprint towards which humans could aspire and, as an ideal form (or kind of virtual reality), could inspire and guide humans in their ethical behavior and in their temporary earthly cities. ${ }^{3}$ For Aquinas, a neo-Aristotelian, the ideal city could only be grasped by the divinely commissioned monarch who served as God's emissary on earth and who alone was capable of understanding and translating the will of God for the people he ruled in the earthly city. ${ }^{4}$ For both Christian philosophers, the ideal city was no longer attainable through adopting individual virtues such as courage, honesty, and loyalty but only through the higher spiritual and Christian virtues of faith, love, and hope-a city which one could only hope to enter in the next world.

Thus, moving quickly as I have done through the medieval development of cities that were established around churches and fortifications in Europe (as well as the temples and fortifications in Asia), we come to the period of modern industrialism and the emergence and eventual domination over the earth's cityscapes of capitalism. Charles-Pierre Baudelaire, the quintessential Romantic poet of Paris and Europe, refashioned the aesthetic of the imagination and the beautiful, which included the 'city beautiful' idealized by Plato and Aristotle, and its Christian "City of God" variants by Augustine and Aquinas. His refashioning took the form

\footnotetext{
${ }^{3}$ See Augustine City of God against the Pagans. Edited and translated by R.W. Dyson. Cambridge, England: Cambridge University Press, 1998

4 Thomas Aquinas, following Aristotle argues that the city is the perfect human community because of its self-sufficiency and how it leads the human to the life of Christian virtue:
}

[Aristotle] says that the city is a perfect community; and this he proves from this, since every association among all men is ordered to something necessary for life, that community will be perfect which is ordered to this, that man have sufficiently whatever is necessary for life. Such a community is the city [civitas]. For it is of the nature of the city that in it should be found everything sufficient for human life ... for it is originally made for living, namely, that men might find sufficiently that from which they might be able to live; but from its existence it comes about that men not only live but that they live well insofar as by the laws of the city human life is ordered to the virtues.

This is from Thomas's Commentary on Aristotle's Politics, Book I. Lecture I, note 23. For an alternative translation, see Commentary on Aristotle's Politics. Translated by Richard J. Regan. Indianapolis/ Cambridge: Hackett Publishing, 2007. 7. of romanticizing the city highlighted by the difference in the 'citified' cultural values of the modern bourgeois class and the elite, the 1000-year heritage of the Greco-Roman aristocracy of Plato and Aristotle. ${ }^{5}$ Simply put, Baudelaire poeticized the often-times hopeless and hapless search for beauty that emerged in the modern industrial cities of nineteenth century Europe. No matter how hard life was in the modern industrial cities of Europe, a hardness which led Baudelaire to proclaim that suicide was the sign of the modern city, hope was still possible. His most famous work, Les Fleurs $d u$ Mal (The Flowers of Evil, 1857) was written at the onset of the period of 'Baron' von Hausmann's destruction and reconstruction of Paris (1853-1870) which set in motion the phenomena of anonymity and alienation which have become the lasting legacy of the cities of modernity. ${ }^{6}$ This critical period also marked a fundamental transition in the formation of modern cities as the locus of the articulation of meaning, high and low culture, and the advent of the age of commodification - the mood of which Baudelaire captured in his poems and about which the German philosopher-journalist Walter Benjamin would be inspired to construct one of the most remarkable texts in the philosophy of the city stream of thought, namely, Das Passagenwerk (Arcades Project) mainly while living in exile in Paris, having fled from the Nazis and his childhood home of Berlin. ${ }^{7}$

\footnotetext{
${ }^{5}$ See Benjamin, Walter. Charles Baudelaire: Lyric Poet in the Era of High Capitalism. Translated by Harry Zohn. London: NLB, 1983.

6 To get a sense of Baudelaire's poetry of the city, see his most famous work, The Flowers of Evil (Les Fleurs du mal; bilingual edition). Edited by Marthiel Mathews and Jackson Mathews. New York, NY: New Directions Publishing, 1989. See especially the subsection, Tableaux Parisiens for his criticism of $19^{\text {th }}$-cenury French modernity and poeticized expressions of phenomena such as the anonymity and estrangement that resulted from and that are common maladies of today's global metropolises. He was inspired by the gamblers, prostitutes, and all other victims of the heavy-handed imperialism that affected the city. See also related analysis of how the city of Detroit embraced the ethos and practices of the 'city beautiful movement' adopted and implemented by U.S. city planners, city managers and mayors, and architects in cities such as New York City, Cleveland, Chicago, and Washington, D.C., a movement that began with Hausmann's infamous (or famous, depending upon one's perspective) reconstruction of Paris in the middle of the nineteenth century. See Jules Simon, "Welcoming Newcomers and Becoming Native to a Place: Arendt's Polis and the City Beautiful of Detroit" in Philosophy of the City, a Special Issue of Open Philosophy, 3(1), edited by Sanna Lehtinen. Berlin, Germany: Walter de Gruyter GmbH, 2020, 586-598. https://doi.org/10.1515/opphil-2020-0130.

7 See Walter Benjamin, The Arcades Project. Translated by Howard Eiland and Kevin McLaughlin. Cambridge, MA: Belknap Press, an imprint of Harvard University Press, 2002. For an interpretation of Benjamin's work that complements this work, see my article, "The Socially Transformative Aesthetics of Street Culture: from Walter Benjamin's One-Way Street to The Arcades Project" in Urban Aesthetics Special Volume 8, 2020 in Contemporary Aesthetics edited by Sanna Lehtinen; (https://contempaesthetics.org/2020/07/16/the-socia lly-transformative-aesthetics-of-street-culture-from-walter-benjaminsone-way-street-to-the-arcades-project/).
} 
This quick 2000-year 'history of the city' brings us to the twentieth century and Lewis Mumford-the writer, American historian, sociologist, philosopher of technology, and literary critic - who published The City in History: Its Origins, Its Transformations, and its Prospects in 1961 for which he won the National Book Award for non-fiction in $1962 .{ }^{8}$ Mumford contentiously argues that the structures of the modern city have led to many of the modern problems of environmental degradation and social injustices that began to plague the cities of our world in the first half of the twentieth century when the industrial age was synergistically combining with maximum effectiveness with capitalism and technology. As we all now know, this synergy was fueled by the relentless techno-industrial extraction of fossil fuels which has helped to create not only the megacities that began to emerge in the mid-twentieth century but also what I have termed the phenomenon of urban desertification which has directly led to global warming. ${ }^{9}$ But decades before I came up with that concept, Mumford was intent on theorizing an argument for reestablishing a more organic relationship between people and their city living spaces. Indeed, in direct contrast to the objective, quantifiable metrics with which I began this Introduction and which the United Nations employs for their admirable attempt to direct a ray of attention on the role that cities are playing and will increasingly play for the future of our earth, Mumford claimed that " ... it is art, culture, and political purposes, not numbers that define a city." 10

Significantly, Mumford turns our attention to the medieval city as the basis for the "ideal city" in similar ways that I have laid out in my brief sketch. He claims that the modern Euro-American city is too closely modelled on the Roman city which took shape as a relatively disorganized, urban-suburban sprawl with inadequate social services. Eventually, as we also know, the city of Rome and the Roman empire collapsed, and Mumford argues that modern cities will meet the same fate if city dwellers continue to not act with more intentional care about how humans express their urban spirits. While he was critical of the suburbanizing sprawl and technologizing alienation of modern urbanization, Mumford also thought that the city is produced by the earth and is, simply, a fact of nature and is one of the primary modes of how humans express themselves. Some of the enduring prophetic elements of Mumford's work are

\footnotetext{
${ }^{8}$ See Lewis Mumford, The City in History: Its Origins, Its Transformations, and Its Prospects. Boston, MA: Mariner Books; an imprint of Houghton Mifflin Harcourt, 1968.

9 See Jules Simon. "Urban desertification and a phenomenology of sustainability: the case of El Paso, Texas" in Interdisciplinary Environmental Review, (IER), Vol. 15, No. 2/3; Geneva, Switzerland: Inderscience Publishing, 2014; pp. 160-182.

10 The City in History, 125.
}

in how he recognized the many crises facing modern cities and in how he was especially distrustful of the growth and power of the finance industry, the lack of strong municipal political structures and, most of all, that local forms of community culture were not being supported by the financial and political institutions of the city. A concise distillation of Mumford's ethically normative philosophy of the city is that the physical design and economic functions of the city should be secondary to the city's relationship to the natural environment and to the spiritual values of the diverse human communities that make up the city. This is none other than the language of sustainability decades before humans became aware of the importance of that way of thinking.

One of the most important themes that Mumford develops is the distinction between village and city, a distinction which remains relevant for contemporary city planning, design and management. Where one has to be a generalist and a jack-of-all-trades in the village, knowing and doing everything for the sake of one's daily life, the city is the place where specialists are formed and thrive. Mumford notes that cities came about because villagers developed institutions that needed specialists to take over and care for them: " ... the embryonic structure of the city already existed in the village.... House, shrine, cistern, public way, agora—not yet a specialized market-all first took form in the village." ${ }^{11}$ But the city is not a big village; rather, where the village is a place of equals, the city is governed by caste and hierarchies with rulers and subjects, temples and forts. Where labor in a village is communal and mutual aid is common, there is division of labor-specialization (which is essential for industrialization) - and competition that essentially drives the business of the city. As the village transforms into the city, "...the maternal enclosure and intimacy and its oneness with the forces of nature were carried over to the city...." However, Mumford notes, "When these primary bonds dissolve, when the intimate, visible community ceases to be a watchful, identifiable, deeply concerned group, then the 'we' becomes a buzzing swarm of 'I's' and secondary ties and allegiances become too feeble to halt the disintegration of the urban community." 12 One can sense how Mumford is able to provide his own diagnosis of modern urban alienation with such lines of thought.

In a writing career that spanned 60 years, this short introduction cannot do justice to the complexity and richness of Mumford's contributions to a philosophy of the city. But one of the most important of his ideas is that of organic humanism since that phenomenon, the irreducibility of humans in their natural, organic condition-like all animals, humans need clean air, nutritious food, and bodily

\footnotetext{
11 Ibid, 19.

12 Ibid, 15.
} 
companionship — essentially structures the entirety of his thoughts on the modern city. This commitment to the naturality of the human condition, especially as humans find themselves denatured in modern cities, enabled him to be critical of what he considered to be the runaway train of technology and technics and how that process has progressed in deleterious ways for the modern city. For Mumford, pursuing technological advancement has had negative effects on the individual human organism and the social through the creation of noise, radiation, and pollution - both air, light, and poisonous chemicals-which has led to the destruction of countless human lives and the natural environment through the production and implementation of war machines, guns, and bombs that humans have invented and used to dominate each other and the earth as ways to maintain privileges of race and class. In this issue, Taylor Stone's article addresses one aspect of this issue with his phenomenological ethics of urban light pollution in modern cities.

Mumford's critique of the city and thus his vision of how cities should be are both organized around the nature of human bodies, a correlative correspondence which is essential to all of Mumford's work on city life and urban design. Such a correspondence is rooted in his concept of biotechnics which basically means "livability." Thus, the corollary to his concept of organic humanism is his concept of a biotechnic society which takes shape in what healthy and holistic cities contain and thereby, since it is 'good' for the organicity of the human, magnetically attract humans to cities by way of migration and the dynamics of human freedom, mobility, and the desire for spiritual association. From a phenomenological and holistic perspective, humans, as naturally organic beings, are organically attracted to what cities contain especially when cities, embodied as a biotechnic society, collectively direct themselves toward the productive play of technology and the basic forms, drives, and desires of social interactions, of humans with each other and their eco-milieu. This results in much more qualitatively rich, deeply and broadly expansive, creative expressions of freedom because they are not limited by quantitative pressures and crowding. Ideally, as cities allow for organic humanism and biotechnic play, society is able to experience greater self-regulation, self-correction, and self-propulsion and better-more sustainably - attend to its need for healthy food, controlled and limited forms of reproduction, desirable growth, and resilience.

The City in History is filled with many philosophically rich insights and I conclude my brief overview of it with some phenomenological comments by Mumford that have to do with the integrated form of the structure and function of modern cities and that provide a touchstone for my comments on the articles included in this special issue. Mumford notes that, "For a great part of urban history, the functions of the [city as] container remained more important than those of the [city as a] magnet: for the city was primarily a storehouse, a conservator, and accumulator." 13

However, he noted, the city is not merely a container because before it can contain anything in any kind of a lasting and sustainable way, it has to attract people to its institutions, its promise and possibilities, and to its secular and spiritual values of various forms of life and of love. He notes: "Thus even before the city is a place of fixed residence, it is a meeting place to which people periodically return: the magnet comes before the container, and this ability to attract nonresidents to it for intercourse and spiritual stimulus no less than trade remains one of the essential criteria of the city, a witness to the inherent dynamism as opposed to the more fixed and indrawn form of the village, hostile to the outsider." ${ }^{14}$ Understood as a container, cities provide for the possibility of a closed field that would promote the maximum levels of diverse interaction, of mixing and merging, of cooperating and collaborating. But this 'closed field' must paradoxically remain open to the influx of outsiders, of foreigners and aliens, of immigrants and exiles, and thus open to new forms of producing that ancient Greek virtue of eudaemonia-flourishing. Because it is precisely the third foundational element that Mumford identifies as the most important for characterizing what cities mean for us, and that is their predictably unpredictable transformative potential: "The walled urban container indeed has not been merely broken open: it has also been largely demagnetized, with the result that we are witnessing a sort of devolution of urban power into a state of randomness and unpredictability." 15 With these final words, Mumford challenges us to rethink our dogmatically entrenched thoughts of the city, colored by the biases and prejudices of binary oppositions of city vs. country, technology vs. nature, upper class vs. lower class, insider vs. outsider, and the myths of national sovereignty vs. local control. Instead, our modern, contemporary, cosmopolitan cities have become and will continue to become the kind of places where we explore the fluid boundaries of such oppositions and challenge the fixed categories that limit our infinite potential to transform ourselves through transforming our relationships with others. Cities are where we work and live, where we find and experience love, where nature and technology harmoniously coexist and, ultimately, where we can-if we hold ourselves open to the ever-changing horizons of possibilities-experience the very transformative value of the city in itself.

\footnotetext{
13 Ibid, 97.

14 Ibid, 10.

15 Ibid, 34.
} 


\section{Contents of the Special Issue}

This special issue testifies to the growing importance of thinking philosophically about the role of cities in worldmaking. Each of the contributions is directly associated with activities of the Philosophy of the City Research Group, exemplifying the commitment of the members of the Board of Directors and the Research Group to advancing new paths of writing and research to this emerging field of study. The international Philosophy of the City Research Group is an eclectic consortium that regularly brings together philosophers and other scholars and professionals with an interest in the phenomenon of cities and works to develop and promote the Philosophy of the City as a branch of contemporary philosophy. From the beginning, leaders of the Research Group intentionally engaged with a broad, interdisciplinary range of intellectuals, artists, and city officials associated with modern cities which has included: city planners, mayors, environmentalists, street artists, ecologists, geographers, and architects, among other disciplines and professions. As a collaborative and strongly interdisciplinary working group, its members find themselves addressing practical city issues that entail crossing disciplinary boundaries and challenging the self-imposed limits of professional, academic philosophy.

One of the most important functions of the work of the PotC Research Group has been its commitment to organizing international conferences in cities that have been historically central to the development of thinking about different facets of the phenomenon of cities: Brooklyn, NYC, USA (2013); Mexico City, Mexico (2014); Hong Kong, China-Portland, USA-Mexico City, Mexico (2015); San Francisco, USA (2016); Porto, Portugal (2017); Bogotá, Colombia (2018); and Detroit, USA (2019). These conferences have attracted anywhere from 50 to 100 participants each and because of the success of the PotC Research Group, a decision was made to begin offering collaborative Summer Colloquia limited to no more than twenty participants, with more demanding selective criteria. As of the writing of this issue, two such Colloquia have been staged, one in 2018 in Enschede, Netherlands and the second in 2019 in Lahti/Helsinki, Finland. The international PotC conference planned to be held in Bilbao, Spain and the Summer Colloquium planned to be held in Warsaw, Poland during 2020 were canceled due to the COVID-19 pandemic and now the network is committed to continuing its activities online as long as is necessary. It seems clear that global challenges such as the pandemic (ongoing at the time of this publication), along with the ongoing climate crisis, require that philosophers who care about the health of each other, our cities, and our one planet earth need to continue to develop new methods of collaborating with each other and to responding to the challenges that continue to face us in the many different kinds of cities within which we live, move, and find our meaning.

\section{Section One: Ontological Postulations}

This particular issue is a small sample of the kind of work being done by the PotC Research Group, featuring nine blind peer-reviewed articles selected for how they contribute to some of the central themes highlighted in this Introduction. Although relatively few in number, the sample size is high in quality. I have organized the articles of this special issue into three groups with the first two articles advancing the work of philosophizing the city in terms of ontology and metaphysics. The second set of articles are more historically oriented analyses and the third set provide a selection of phenomenological perspectives, demonstrating some of the range of the research projects associated with the PotC Research Group.

In the first article, "What is a City?" Achile Varzi provides us with an essay based on what he says are four simple words but that, in being asked and explored, powerfully evokes the metaphysical phenomena of change and enduring identity with respect to how we experience the city. Varzi raises this simple question and continues with another: how can the city both remain the same and yet constantly change? And his answer is as straightforward: we experience the city as one and the same while also experiencing its changes because the city is not an ontological thing but a functional process. This first essay is especially important since it raises critically important methodological issues that constitute why and how research on cities is uniquely benefitted by situating the city as an object of philosophical study, both logically and empirically, taking into account the broader context of the philosophical and social scientific literature devoted to the nature of cities. More specifically, Varzi begins his essay by raising the issue of motivation with respect to addressing what moves us to speak about cities in this or that way which presupposes a prior commitment to not only understanding the audience with whom we are engaged but to more clearly understand the object that arouses the interest of that audience, in this case 'the city,' as such. Varzi gets to this point by first situating the city as an object of study in familiar philosophical terrain, namely, the implicit Cartesian framework of dealing with the city by way of a pre-established dualism of mind and body or, in the case of the city, of physicality and social relevance. What makes Varzi's essay distinctly significant for this special issue is in how he takes up as his case study Mumford's work on the city as "inspiring" the entire domain such that “...Mumford's essay is rightly regarded as a benchmark of 
modern urban studies." However, his critique is quick to follow as he questions the unexamined presuppositions of Mumford's approach:

Nonetheless it betrays exactly the sort of dualism between the physical and the social that I want to resist. It's not that I am opposed to it; I just think it goes too far. I am interested in the question "What is a city?" insofar as it can and ought to be answered before we embark in such distinctions, before we begin to differentiate between the physical dimension from the social one. I feel the same about other popular ways of addressing the question by emphasizing the multilayer complexity-physical, social, economic, political, ecological, and environmental—of cities.

For Varzi, the concern has to do with both intentionality and with disciplinary specificity, ironically-from my perspective-doing precisely what Mumford notes in his work differentiates the intellectual work of a villager from the intellectual work of a city-dweller, namely, he specializes. Indeed, Varzi employs a distinctly familiar philosophical approach when he situates his questioning of talks about the city in general as the context from what he considers the more purely metaphysical concerns of definition and explanation. As he notes:

...my concern is with the nature of the definiendum. If you like, the way I want to understand the question is so basic as to qualify as strictly metaphysical. I said that when we speak of Rome, Beijing, New York, etc., our words are rushing too swiftly over their referents. Well, what kind of referents? How are they supposed to differ from other things we often name or talk about, such as people or books or stars or rivers? That's my question.

By raising the question of what constitutes the philosophy of the city 'as such,' Varzi provides a valuable and enduring framework, from the perspective of practicing conceptual analysis as one means for how to effectively carry on the work of studying the nature of the city philosophically.

In the second article, "The Concept of Rationality for a City," Kenny Easwaran argues for thinking about the city as a rational, collective agent. After initially canvassing a variety of ways that the word city is used to designate various sorts of collectives of people, Easwaran states that a defining characteristic of his reflections on the city entail thinking of the city as a "community of people whose daily lives are tied together by geography, rather than a governmental entity or a legal border. Importantly, this includes the suburbs and outlying neighborhoods, and not just the very central core. Furthermore, it is essential to my project that the focus is on the collection of people defined by their geographic proximity" which includes the structures and infrastructures built by people as well as the geography of the space as long as they are "structured by the activities of the people," that is, by what Easwaran considers to be the rationality of their social norms. Indeed, while not stating it explicitly, Easwaran's intent is to establish a normative vehicle for evaluating the functioning of urban areas in general, using the standard of rationality.

However, he presents his position as neither entirely descriptive nor prescriptive but rather somewhere in between the two options: "Notions of rationality are often considered to be either explanatory (showing why certain behavior occurred) or predictive (giving a guide to what sort of behavior is to be expected). My account is not quite either-it is instead intended to evaluate how well some individual or community is doing at living up to its own goals." Easwaran qualifies that "living up to its own goals" is a standard that can be characterized in terms of identifying the kinds of "shared desire that can shape shared behavior" and that then extends to notions of shared agency and shared rationality. He maintains that these latter standards—-shared agency and shared rationality - as metrics, are especially "pronounced" at the level of the city and that rationality, understood in this way, can promote the instrumental interests that all humans share who live in the kind of "shared embodiment and geographic proximity" that we call cities. To end his article, Easwaran contends that he does not have to specifically articulate a principle such as "justice as fairness" because, if a city is rational in the way that he outlines, it will necessarily provide clear water and air as well as good public transportation and fair wages for its residents.

\section{Section Two: Historical Orientations}

The third essay, "Natural Tensions in Aristotle's Polis and Their Modern Manifestations," by Gregory Kirk, analyzes "Aristotle's organic analogy when discussing the different "organs" of the Greek polis" in order to demonstrate how it generates tensions between said "organs" in the Greek polis, such as those between unskilled manual laborers and other members of the polis. Kirk argues that because of its naturally fixed stratification, Aristotle's polis does not allow them to enjoy the "chief virtue of political life" which is "human virtue and the good life." However, Kirk postulates that the possibility exists that by virtue of their disenfranchisement, those members who are not enjoying themselves at least experience the possibility of what he calls a "second best" kind of sensuous recognition and thus are able to at least experience something excellent and contribute to the overall thriving of the polis, even though they cannot fully experience the "greatest and primary benefits" that the polis has to offer. He extends his argument by contrasting that Greek situation with that of the modern city where the 
natural and visible tensions that existed in the Greek polis are concealed.

The biggest difference that contributes to this phenomenon of concealed tensions is that the city in our time is part of a nation-state and thus many of the functions of the former polis are taken up by the state rather than this or that city. Kirk notes that, where citizens of the Greek polis lived within a whole, contemporary city dwellers live within a part of a larger whole. This results in both a quantifiably heightened amount of diverse human contact but, simultaneously, diminished and infrequent and even absent cultural practices. Consequently, the fewer interpersonal contacts that do occur tend to be more "impersonal, superficial, transitory, and segmental" leading to the greater propensity of living anonymously among strangers and obscuring "the immediate, sensuous apprehension of the way in which [the city] is organized" such that even the "cultivation of a psychology of independence from a larger whole" which was possible in the Ancient Greek polis as a "second best" becomes impossible. The resulting "competition, aggrandizement, and mutual exploitation" leaves modern city dwellers with no means to resolve their tensions. This is amplified by the fact that in the modern city there is no single, coherent purpose to which the city aims. Individual human beings living in a city do not have a direct, sensuous experience of what whole it is that their labors are contributing to because there is no such immediately available whole. Contemporary urban living is therefore abstract, and this abstraction encourages group-, factional-, or self- interest that is separated from any putative whole; this is, indeed, the most understandable response when there is no whole with which to identify.

The fourth article by Diana Gianola, "City and Democracy in Max Weber," provides an analysis of Weber's thought about the city from oft-neglected works of his such as The City (published 1921) along with more well-known texts such as The Protestant Ethic and the Spirit of Capitalism and the massive Economy and Society, published post-humously in 1924 by his wife, Marianne (Schnitger) Weber-an influential feminist author in her own right, in order to highlight the philosophical relevance of his sociologically oriented analyses of how democracy developed out of the multi-causal effects of the communes of medieval cities. She points out that even though Weber's analysis focuses mainly on medieval communes, his philosophy of the city is worth exploring because of how he tries to grasp the essence of the city, as such, and for how he contends that the "medieval city embodies the ideal-type of the democratic city." This is the case because of how the medieval city was born out of a "revolutionary usurpation" against feudal and noble powers and took shape in the form of "non-legitimate power." Thus, what is usually neglected in histories of the medieval city is that they were thereby the source for principles and practices of freedom, autonomy and the formation of a mutual responsibility of the citizens, based on their consideration of other citizens of the city as equals.

Additionally, Gianola guides us into Weber's reconstruction of the formation of an urban middle class that introduced a series of economic innovations in the middle ages, such as a larger market and free labor. Medieval city dwellers also experimented with new accounting techniques and legal tools for trade and, unlike the Ancient Greek polis, which focused primarily on consumption, the medieval city developed structures of production that ultimately led to modern forms of capitalism. Hence, since for Weber the "city does not exist without democracy and democracy lives in the city... [it is not that surprising how]... Medieval communes and megacities—again—do not appear so distant, at least not in their aspiration for democracy."

However, Gianola notes that for Weber the usurpatory character of urban aggregation reveals a paradox, which links one thematic thread of her article with Easwaren's "The Concept of Rationality for a City," and that has to do with the fact that the association of revolution with the city "seems to speak the language of irrationality." However, for Weber, the city also embodies rationality in the social sphere: in concentrated housing, in how an economic rationality generates the acquisitive economy, and the rationality of politics, defense, and other forms of social organization. But ultimately, contends Gianola, Weber is not concerned with defining the city, as such, but instead contends that "the origin of the city as usurpation already anticipates the reason of the impossibility to define it because it is essentially a rupture, an excess." What this means is that, per Weber, "even rationality cannot fully understand it, and its pretentious rationality-social, economic and political-is uncertain if analyzed in its tangible historical forms. Not even the city is as rational as it pretends to be." She goes on to note that the very failure in defining the city and, especially, the "failure of its rationality in the history of urban experiments," combined differences between the medieval commune and the modern city, is not the end of the city or of theorizing about the city. Instead, those failures call attention to the city's authentic meaning, namely, "its broken nature, and its constant need to reinvent and outdo itself."

The fifth article, Matthew Crippen's "Contours of Cairo Revolt: Semiology, Values and Affordances in Political Street Discourses," provides a contemplative account of how symbols and values can be correlated with the physical and cultural landscape of a city, taking for his case study the 2011 uprising in Cairo, Egypt. He specifically focuses on events surrounding Tahrir Square in Cairo and how the Egyptian national flag was used in street discourses. What 
distinguishes Crippen's analyses of a specific series of events in a specific place in a specific city is how he brings James J. Gibson's influential theory of affordances, from his 1966 book, The Senses Considered as Perceptual Systems, to fruitfully bear on his interpretation of the events as an instance of using urban design to achieve and maintain oppressive military control of a people. His focus on a specific physical place and social space in the city has to do with his general observation that, "By virtue of being social, built environments [such as cities] manifest greater varieties of values and do so more richly." As he notes in his conclusion, post-2013 alterations to Tahrir Square by the military regime that led the 2013 coup, cordoned off the Square and closed it as a public space where dissent could take place in that city. For Crippen, this results in raising ongoing concerns about the possibility of any future dissent in the city, demonstrating, as it were, the ongoing viability of Weber's contention that a genuine foundation of democracy in the city is its ongoing irrationality and openness to revolution or dissent.

Crippen examines the intertwining of oppressive nationstate control, in this case the military regimes of Egypt, postBritish occupation, with how revolution, rebellion, or dissent occurs and is associated with symbolic artifacts, such as the Egyptian flag and an historic place, Tahrir Square-Tahrir, translated from Arabic, means liberation. However, in order to maintain control in the place of revolution, in the central square of a city which serves as a gathering place for the citizens of the city to voice opposition or unity, the nation-state appropriates both symbol and place in ways that genuine democracy, which includes the possibility for public oppositional dissent, can effectively be silenced. Crippen's article also raises issues of how modern city dwellers, and modern cities, are parts of a larger national whole, complicating and limiting expressions of independence, freedom, and democracy. As he notes partway through his article, the national flag and Tahrir Square were used by both those attempting to assert their independence and freedom from military repressions, the Egyptian governing party, as well as used-appropriated as affordances-by the rulers of the nation-state in order to maintain forced national identity and unity and the ongoing submission of those they ruled. As Crippen notes, the battle for Tahrir Square-for Liberation- "was-and continues to be- preeminently about values, ideas and meanings, and attempts to own and reshape them." What reshaping in this case has meant is that the people of Cairo have not only had barriers erected that symbolically close the square for oppositional gathering and as a space for oppositional representation but the "closure of Tahrir mirrors a broader closure of intellectual space in Egypt" as a whole.

\section{Section Three: Phenomenological Perspectives}

Article six by Vesa Vihanninjoki, "Urban Places as Aesthetic Phenomena: Framework for a Place-Based Ontology of Urban Lifeworld," reconsiders understandings of place concepts by providing an "alternative reading of urban places and the related aesthetic dimensions, based primarily on a Heideggerian account of human existence as placed being in the world." The key conceptual distinction made by Vihanninjoki are those having to do with an object-based and a contextual interpretation of place in order to better understand the aesthetics of place and, thus, the role that place-making plays in constituting and reconstituting the lifeworld. Following up on Crippen's theme, he challenges the centrality of place-making notions in how they have been used to justify any and every policy, especially when such notions are used to assume authoritative positions for determining policy decisions in urban contexts. Vihanninjoki highlights this problematic, that place-making can mean practically anything and thus ostensibly nothing, in how they have had "economic connotations: particularly in the context of design-oriented urban planning, place-talk often follows the logic of the globalized and mobility-oriented financial world-that is, the logic of marketing and branding."

Because of these socio-economic considerations, Vihanninjoki utilizes the tools of Heidegger's phenomenological hermeneutics in order to sort through historically evolving terms related to place-making. He takes note how "changes in the applied conceptual framework might be best described as a shift in focus: where the term "embodiedness" highlights the concrete physicality and the consequent physical preconditions and possible limitations that frame human existence... "situatedness" brings forth the abstract, temporally and historically defined systems of meaning (the "hermeneutical horizon") among which we find ourselves." He then highlights how "placedness" combines these two approaches, thereby orienting our human bodies and essentially comprising how we understand and live out our possibilities and obligations in this world, emphasizing how adequately understanding "placedness" provides important insights into the "material and immaterial contexts that continuously and inevitably frame people's everyday life." Thus, an aesthetics of urban places that takes into account how such aesthetics define and redefine our urban lifeworlds according to some particular conception or ideal of urban life, is exceptionally relevant for understanding the ideological and political currents of our diverse and complex city lives.

Article seven by Whitney Howell, "Anonymity and Diversity: A Phenomenology of Self-Formation in Urban Culture" 
deepens and yet complicates Vihanninjoki's thesis through a phenomenological analysis of the unreflective dimensions of our embodied, urban and multicultural lived world experiences. She utilizes Merleau-Ponty's account from his Phenomenology of Perception to demonstrate how bodily capabilities are rooted in unreflective, or "anonymous," resources furnished by our urban environments as a way to analyze the experience of inhabiting a city which, Howell argues, "encourages the development of a perspective inclusive of diversity that offers a means of challenging forms of social and political oppression." Ultimately, she maintains that it is imperative to give voice to diverse experiences that are quintessentially found in the city in order to challenge the "oppressive social and political structures we discover in the anonymous dimensions of urban experience."

Following a rich analysis of Merleau-Ponty's phenomenology of the perceiving body, Howell challenges the superficial reduction of phenomenology as 'merely' a first-person account of experience, simultaneously drawing our attention to the inadequacies of explaining experience through the presupposition of an independent, causal reality. Following Merleau-Ponty's lead, Howell reminds us that one of the central insights of phenomenological analysis is that our experience is not simply reducible to a first-person perspective but embedded in and thus shaped by impersonal or anonymous conditions. In fact, the "anonymous and general existence" of the body as physical organism subtends and informs the actions and decisions characteristic of our personal lives. It does so, as body, by prolonging "personal acts into stable dispositions [and] habits [that] reveal our distinctive way of doing things but, as unreflective, add generality to our experiences.

Howell's thesis takes shape in how she then relates those thoughts about the body with a set of claims about the urban environments in which we find ourselves, specifically, that "different environments inform the development of different capabilities and, in turn, shape different versions of the anonymous existence out of which we create our more specialized, personal lives." These "anonymous dimensions of our experience and their relation to the environments we inhabit" have significant implications for the nature of our participation in what I also alluded to in the opening section of this Introduction, namely, to our increasingly urban and multicultural world. Howell fortifies her claims about diversity by drawing from a panoply of diverse sources, such as: Louis Wirth's ideas about the social diversity of cities, and the frequency and apparent superficiality of one's relations with others in a city, found in his classic essay, "Urbanism as a Way of Life"; Jane Jacobs' claims that diversity is essential for the health of the city from her classic text, The Death and Life of Great American Cities; Eva Kittay's analysis of "dependency work" from Love's Labor: Essays on Women, Equality, and Dependency; and Réal Fillion's argument that inhabiting a multicultural space fosters "the recognition of unfamiliar familiarities," in his Multicultural Dynamics and the Ends of History. An especially noteworthy example is Howell's use of the Syrian architect Marwa al-Sabouni's description of how the social environment of cities like Damascus in the early Islamic period fostered the acceptance of differences among residents by how residents were "taught" openness to others by the urban environment itself-not through textbook lessons or civic policies-but through their lived experiences of "seeing new faces, talking different tongues." Such lived world experiences "illuminated the depth and richness of ways of life different from their own."

Those claims are brought together in the final section of the paper through an interpretation of Merleau-Ponty's "The Body as Expression and Speech," namely, that what is uniquely distinctive about our urban environments is their social diversity and that, in order to challenge the oppressive social and political structures that we discover in the anonymous dimensions of our urban experiences, we need to cultivate perspectives that are more inclusive of difference and that are able to amplify our individual powers of expression. Howell's conclusion is that "giving voice to diverse experiences is a crucial complement to the challenge to oppressive social and political structures we discovered in the anonymous dimensions of urban experience." The expression of diverse experiences explicitly counters a predominant, oppressive narrative that persists in our self-conscious interpretations of ourselves and others (whether or not we are the benefactors of this narrative). Furthermore, it motivates our recognition of what our reflective "I" actually includes, namely, the rich experience of inhabiting a world of diverse others.

Article eight, Taylor Stone's "Re-envisioning the Nocturnal Sublime: On the Ethics and Aesthetics of Nighttime Lighting," is a welcome addition to this issue in the way that he addresses some of the practical problems of light pollution in modern cities. With striking originality, Stone examines the aesthetic dimensions of urban and natural darkness explicitly invoking Kantian conceptions of the sublime, mathematical and dynamic, in order to highlight aesthetic, environmental, and moral differences between experiences of the natural night sky in the wilderness versus our experiences of artificial, nighttime lighting. He proposes that we re-envision what he calls "the urban nocturnal sublime, striving for nightscapes that are both aesthetically powerful and morally engaged."

He moves across disciplinary boundaries in order to challenge the geographical dualisms of cities and wilderness, troubling that distinction in order to mount a critique of the moralizing biases associated with the ideology of progress since the Enlightenment which began to shape minds and practices in the middle of the seventeenth century. Stone's research traces the historical accounts that put forward the 
thesis that “... the ramifications of nighttime lighting are as much a product of symbolic and social meanings as technical innovation or functional purpose. Artificial illumination has long been positively associated with values such as safety and progress, while darkness has maintained antithetical associations with danger, evil, and primitiveness." The very idea of light in its practical and symbolic senses has been associated with modernization and the "Enlightenment project" in such a way that lighting itself has taken on a metaphorical moralizing tone as a force for good in order to banish the ignorance of darkness in modern society. His aim is to challenge longstanding connotations of light and dark in conscientious and morally engaged ways. As he notes towards the end of his article, his analysis marks a distinct contribution to an emerging discourse, especially in environmental philosophy and the philosophy of technology, on the ethics of light pollution and nighttime illumination, by examining the combined aesthetic and ethical dimensions of the issue. Rephrasing his closing remarks, by following Stone's illuminating analyses we might be able to begin seeing our cities in a new light.

Article nine, "THE POST-METROPOLIS IS GOD. Notes for a Phenomenology of the Urban Spirit," by Jorge León Casero and Julia Urabayen rounds out this special issue. Indeed, we come full circle, as it were, from Achile Varzi's contention of the "city as process" to an analysis of the formation and planning of cities in terms of consumption and production by Casero and Urabayen that likewise leads us beyond earthly and maritime conceptions of the city with their fixed spatio-temporal coordinates to the techno-industrial city and 'airborne' nature of our information age that "implies the loss of all fixed (earthbound or earthly) or mobile (liquid) measurement in favor of the appearance of immediate entities whose production processes are not perceptible."

Historically, spatially, temporally — to what do I refer when I conceive of the city as surging and resurging through time? Instead of posing the ontologically imbued metaphysical question, "What is a City?" as Varzi does, Casero and Urabayen pose the question, how do we understand the function or 'process' of the city as a means of production? This is both a phenomenological and an ethical question since it depends upon the quality and quantity of our descriptions of the function of how humans have worked in, with, and for cities throughout human history—and by extension, addresses the role of cities in sovereign nationstates as parts of greater political entities, another theme of this issue ${ }^{16}$ This extension poses normative concerns about

\footnotetext{
${ }^{16}$ For various examples of how the theory of "phenomenological ethics," is especially pertinent for guiding diverse interpretations in the field of 'philosophy of the city,' see my articles in the recent special journal issues edited by Sanna Lehtinen, dedicated to themes in the 'philosophy of the city;' op. cit. footnotes 5 and 6 of this Introduction.
}

haves and have-nots, of the values that are at stake in the essential productive processes that constitute each and every city. These kinds of questions are why Casero and Urabayen proceed phenomenologically, that is, because of their simultaneous concern for both describing the historical evolution of cities-not from their ideal origins in Plato and Aristotle as I sketched out in the Introduction-but from "the Roman Empire's concept of civitas mobilis augescens [because] the distinction between the twentieth-century metropolis and the Roman model of a city must be sought in the eminently biopolitical character of the modern-day post-metropolis, conceived by Hardt and Negri as the new hegemonic paradigm of production."

Casero and Urabayen trace how the "shift from the earthbound paradigm to the airborne one (the digital cloud)" reveals the way that traditional needs that humans have had for replacing and expanding the city's structure through regenerating its infrastructure and buildings, the process of extracting surplus value, "no longer depends on the revaluation that sites undergo when their land use changes from "non-urban" to "urban."” Instead, the new kind of "airborne logic which rules over today's city cannot be controlled by regulating the land on which it sits." Casero and Urabayen maintain that "unless new techniques are developed to control the processes by which immaterial urban space is revaluated, the only thing we can expect to see is how the current laws -both public ones (administrative) and private ones (real estate, mercantile ones)_governing urban spaces will become progressively and incrementally ineffectual." Their article attempts to synthesize the logic behind the changes that are going on in the urban paradigm which is needed in order to disclose what they call a "new force field" that is determining the structure of modern cities.

The body of their article does just this kind of work, conceptualizing various approaches that have philosophically developed to think about how to measure the city in terms of territories, defense strategies against external or internal enemies and this or that historically constructed or socially specific nomos. For example, Casero and Urabayen note how the Greek polis was "structured on a fixed population and maintained through the resources generated by a limited number of inhabitants (when that number increased, a new city was founded)" whereas the Roman metropolis presaged the dynamics of measurement and expansion based on economics, like the modern city. Drawing on Negri, Marx, and Engels, they point out how in the modern urban space, the direction of economic flows functioned differently, such that it allowed "for the flow of capital coming in from the outside and the potentially unlimited growth of its population." This change in direction meant that the existing urban 
space as fixed and limited no longer served as an object to be controlled and measured but rather its "process of growth both in terms of its extension and intensity" [my emphasis] became the object for revaluation. The change was that such a revaluation could not be accomplished merely in terms of property and land, a process which could be said to be rational, as Casero and urabayen maintain, drawing upon Cassirer's analyses of urban property which moves beyond the critique of rational and legal defense of private property mounted by Marx and Engels, in order to introduce a neo-Kantian understanding of the role of public urban space which was associated with Greek religious myth as unlimited and irrational by nature. This spatial-proportional control of domination and rationalization of the urban land on which the effectiveness of private property is based enables the maritime metropolis to develop with its "quantitative, metric system which did not need to maintain a rational proportion between its parts." Drawing on a Foucauldian genetic line of analysis, Casero and Urabayen note that the emergence of perspective with Renaissance city architects allowed for "the mathematical and homogenous ordering of a space constructed rationally and that ultimately becomes a paradigm of Cartesian and Newtonian thought. On the other hand, that same homogenous character-which levels the field for all values-enables the heterotopic appearance of relations that are not hierarchized nor structured according to the spatial order imposed by perspective."

Casero and Urabayen conclude their phenomenology of the city by proposing three alternative models for the future of the city and its post-metropolitan prospects, alternately presenting options by Antonio Negri, Peter Sloterdyk, and Paul Virilio. Negri's model annuls politics in favor of the self-organization of the city as a computerized memory which would entail the "destruction of all cities and metropolises in order to establish worldwide social politics free of space and processes." Out of the three options, Sloterdyk's post-metropolis most resembles currently existing cities, although Casero and Urabayen skeptically note that, for them, it would reproduce the "academic myth of Cultural Studies: a multicultural, pluralist, progressive, tolerant and liberal New York where everything and anything goes." Ideally, its urban space would be the result of the "cohabitation between social differences without conflict and where technology only exists in order to exert greater control over the comfort levels" of the disparate entities. For Casero and Urabayen, Sloterdyk just reproduces a myth derived from Kropotkin's pluralist theory with no connection whatsoever to actual reality and it has no connection whatsoever to the reality of how cities and states actually work. It is simply a "Utopia about ethical citizenship." Virilio's model, as a variation on Smart Cities, is neither based on politics nor on an ethical Utopia and, in fact, no city at all. Virilio's dystopic post-metropolis would take shape as a polarized virtual realm, divided between the wealthy 'haves' who have access to technology and are completely virtualized without body or measurement, and the poor without access to technology, condemned to a desolate imprisonment in territories and suburbs with no laws or values.

\section{Conclusion: Philosophy of the City and the Prospects for Future Research}

This special issue presents a small selection of the kind of high-level, high-quality research that is currently being done by philosophers of the city. The three sections in which the articles are divided also represent only three of the many domains in which this emerging field of research could be organized. There are also the research domains in the philosophy of the city of city planning, street artists, urban aesthetics, technology and the city, smart cities, urban agriculture, and specialty areas such as housing, transportation, public and private spaces, environmental justice, neighborhoods, libraries, museums, immigration, exile, sanctuary cities, and sustainability. All of these threads are weaving together in the loom of the work being done by philosophers of the city and the Philosophy of the City Research Group. In closing, I would like to return to one of the guiding lights of this endeavor whose sagacity I have already referenced: Lewis Mumford. He closes his pathbreaking work on the city with these insightful judgements:

The old separation of man and nature, of townsman and countryman, of Greek and barbarian, of citizen and foreigner, can no longer be maintained: for communication, the entire planet is becoming a village; and as a result, the smallest neighborhood or precinct must be planned as a working model for the larger world. Now it is not the will of a single deified ruler, but the individual or corporate will of its citizens, aiming at self-knowledge, self-government and selfactualization, that must be embodied in the city. Not industry but education will be the center of their activities; and every process and function will be evaluated and approved just to the extent that it furthers human development, whilst the city itself provides a vivid theater for the spontaneous encounters and challenges and embraces of life." 17

Publisher's Note Springer Nature remains neutral with regard to jurisdictional claims in published maps and institutional affiliations.

$\overline{17}$ The City in History, 573. 